\title{
O MENINO OMOLU
}

\section{Cynthia Rachel Esperança ${ }^{1}$ \\ DOI: https://doi.org/10.26512/revistacalundu.v2i1.9561}

Em algum lugar desse mundo, no meio de uma aldeia rodeada de verde, frutos, flores, rios e mar, morava uma tribo chamada Motumbá. Lá as pessoas tinham uma cor tão escura quando a noite. Mas ninguém brilhava mais que OLOKUN, o ancião da aldeia. Ele tinha o poder da oralidade! Um verdadeiro Griot. Quando a noite caía, ele saía de seu bangalô e caminhava bem devagar para o centro da aldeia, ajudado por sua bengalinha.

Com ele, toda a tribo o seguia como um grande cortejo. Ao sentar-se na pedra de Xangô, o vovô brilhava, parecia o céu cheio de constelações. Bem de mansinho, fazia um som que mais parecia um canto de pássaro. As pessoas costumavam dizer que ele estava pedindo à benção da floresta sagrada para contar mais uma história. Pediu que colocasse sua moringa do seu lado.

Logo, ele anunciou que contaria a história do "Menino Omolu".

Os olhos dos moradores pareciam cristais em contato com o sol, o brilho estava por todos os lados. Estavam curiosos para ouvi-lo. Todos bem atentos foram tratando de se acomodar para melhor escutar a história contada pelo sagrado velho. Devagar, como de costume, ele encostou a bengala na pedra. Olhou nos olhos de cada morador e pausadamente disparou: "Peço licença aos meus Ancestrais e aos meus Herdeiros para contar essa história. Se atentem!".

Em um reinado distante, uma mulher prestes a dar à luz, caminhava pelo meio da mata na direção de um rio. Chegando às águas correntes, sentou-se bem na beirinha e pôs seus pés na água cristalina, que refletia a sua imagem. Passou bem devagar as mãos na barriga e sentiu a criança mexer. Pediu a proteção das águas e das forças da floresta para que tivesse uma boa hora. De repente, a criança veio ao mundo, como num passe de mágica. Ainda com os olhos fechados, a pele ferida e vestígios de sangue do parto. Silencioso, não deu um pio.

\footnotetext{
${ }^{1}$ Cynthia Rachel Pereira Lima. Graduanda em Letras - Literatura pela Escola de Formação de Professores da Universidade Castelo Branco - E-mail: cynthiarachell@ gmail.com
} 
A mãe arregalou os olhos, queria respostas para o que via. Mas, para as coisas da vida, nem sempre existem respostas. A mãe olhou para o menino. Enrolou ele com os tecidos que carregava consigo e partiu... O menino ficou ali, enroladinho às margens do rio. Neste momento, era possível notar o olhar triste das pessoas que ouviam atentamente a história.

E, o ancião continuou:

$\mathrm{O}$ dia raiou, e, caminhando pela floresta à procura de ervas sagradas, estava ANAÃN. Uma senhora rezadeira que passara os dias em busca de folhas para curar as pessoas de sua aldeia. ANAÃN achou na floresta: levante, manjerona, arruda, alecrim e outras ervas. Cansada da andança, resolveu repousar à beira do rio. Deixou o balaio no chão, forrou um tecido sobre o arbusto verde, colocou os pés na água e deitou-se em repouso. Com o sol na pele, ANAÃN mantinha os olhos fechados.

De longe, ouvira um barulho, porém manteve os olhos em descanso. Estava muito cansada das andanças na floresta. Quando novamente ouviu um chorinho. Desta vez, levantou-se e cuidadosamente, foi tentando descobrir de onde vinha tal barulho. ANAÃN colocou as mãos na terra e baixinho pediu: "sagrada mãe, já que aqui estou me ajude a entender esse chamado". Com os olhos fechados, segurava a terra. Pedia, pedia e pedia.

OLOKUN fez uma longa respiração e continuou:

$\mathrm{O}$ choro da criança foi ficando cada vez mais alto. ANAÃN correu à procura do som. Estava quase rodeando o rio inteiro, quando o som parou. Sem saber para onde seguir, a moça pediu as forças da natureza para ajuda-la. O tempo nesta hora começou a fechar. O vento levantou as folhas que fizeram um grande redemoinho na floresta. Chuva. Fortes relâmpagos. O menino voltou a chorar. E, ANAÃN a correr. Foi quando ela tropeçou e caiu no chão. Na queda, ela avistou o menino que estava em uma poça de lama, ainda enroladinho com os tecidos que a mãe colocara.

ANAÃN com sua sabedoria, calmamente, foi tira-lo da lama. Conseguiu. O pano que o cobria ficou no buraco. A chuva caia forte sobre os dois. ANAÃN emocionada, ainda sem acreditar no que via, admirava o menino que segurava em seus braços. Conforme a chuva caia, limpava os resquícios de lama do corpo da criança.

OLOKUN fez uma pausa. Pegou a moringa de barro que estava próxima, e molhou a palavra para que a história pudesse continuar. Todos os olhos estavam atentos a ele. E continuou.

Foi desta forma que aconteceu o encontro dessas duas almas. ANAÃN olhava para o menino, que pela primeira vez abria os seus olhos para ver o mundo. Abriu os 
olhos para ver a mulher que lhe deu a segunda vida. Deixando tudo para trás, ANAÃN foi com o pequenino para sua aldeia. No seu cazuá, ela preparou um bom banho de ervas, e enquanto banhava o seu gurizinho, cantava uma cantiga de cura. O menino a observava com os seus grandes olhos. Com uma felicidade que não cabia em si, ANAÃN falou baixinho para ele: "de agora em diante, você se chamará OMOLU - o meu menino, que passou pelas agruras da vida e da morte, resistiu às dores e feridas, foi recebido, guardado e acobertado pelos sagrados elementos da natureza. Talvez a sua missão na vida não seja fácil, mas te dará ensinamentos e você terá que passar para todos os seus filhos e filhas, que serão muitos nesta terra".

E, o menino OMOLU sorriu!

OLOKUN pegou a sua bengala de madeira, levantou-se bem devagar, pediu passagem para os moradores da aldeia e disse como um legítimo sábio: "O que precisamos aprender é que nesta ou em outras vidas, nunca andamos sozinhos".

E, seguiu com seus passos lentos...

Recebido em: 26/01/2018

Aceito em: 10/05/2018 